\section{German proposal draws fire}

\section{Munich}

IN order to help Israel cope with the influx of thousands of Soviet Jewish researchers, Germany last month announced a new DM1 million $(\$ 592,000)$ programme to enable some of those researchers to visit Germany for stays of up to six months. The purpose was to acquaint them both with German scientists and with the techniques of modern research.

But a number of Israeli researchers are criticizing the programme as the wrong way to assist Israel. "Why can't they subsidize Soviet Jews who will be staying in Israel?" asks Yoram Milner, a professor of biological chemistry at Hebrew University in Jerusalem. Milner says the German programme is ill-conceived and sounds "a bit bizarre".

Michael Schlesinger, a professor of medicine at Hebrew University, is more subdued in his comments, but still critical. "In general, this is a worthwhile project," he says, but it is "not the first thing I would have done" with the money. Israel urgently needs funds to absorb the researchers at home, he explains.

Underlying the discord seems to be the unspoken conviction that Jewish scientists who leave the Soviet Union should go to Israel and nowhere else, and German officials know that this is a touchy subject. The German Research and Technology Ministry,

\section{HIGH-ENERGY PHYSICS}

\section{HERA stores protons Munich}

THE $820-\mathrm{GeV}$ proton ring of the HERA electron-proton collider at DESY (Deutsches Elektronen-Synchrotron) was successfully run with its first protons last week. Several 'packets' of protons were stored in HERA at the injection energy of $40 \mathrm{GeV}$.

The next step will be to bring on line the superconducting high-frequency cavities used to raise the energy of the electrons in the ring from $27 \mathrm{GeV}$ to the final energy level of $30 \mathrm{GeV}$. (The electrons circulate in the same ring as the protons, but in the opposite direction, so that they can be directed to collide with each other, with physicists observing the resulting debris of the collisions.) After that, the energy of the protons will be gradually increased in test runs until the final energy is achieved.

If all goes according to plan, the first collisions will come by November, when the two detectors ZEUS and $\mathrm{H} 1$ are due to come on line.

HERA (Hadron Electron Ring Anlage) took six and a half years to build and cost approximately DM1,000 million $(\$ 592,000)$. It is the world's first highenergy electron-proton collider and the first European accelerator to use superconducting magnets. Eleven countries contributed to building HERA, which is located in the Bahrenfeld section of Hamburg.

Steven Dickman here," says Gottstein. Israel in April. GERMANY for instance, says it is aware that the emigrés might attempt to stay in Germany or somewhere else in Europe, where the job market is bound to be better than it is in Israel. Therefore, says Ministry official Peter Gottstein, Germany intends to let Israel choose the researchers who are to come to Germany from among those who already have jobs in Israel. "We're not out to do headhunting

Yael Shinar, a spokeswoman for the Israeli Ministry for Science and Technology, says that there might be changes in the "mode of operation" of the programme, which might allow Soviet emigrés to use some of the money without visiting Germany. But the German Ministry made no allowance for this when it announced the programme during a visit by German Research Minister Heinz Riesenhuber to

The Israeli science ministry estimates that of the 300,000 emigrés in the latest wave from the Soviet Union, some 2 per cent, or 6,000 people, are in scientific research (not

\section{New university for Frankfurt on the Oder?}

\section{Munich}

LED by Peter Wex, a legal scholar and administrator at the Free University of Berlin, a group of academics and politicians in Germany is intent on reviving a university in the eastern German city of Frankfurt on the Oder. That city had a university for more than three centuries until 1811, when it was closed during the Napoleonic wars.

The proposed university, Wex says, could take advantage of Frankfurt's proximity to Poland to offer courses in Eastern European studies and to provide a German-language education to Poles and other Eastern Europeans. Frankfurt, a border town with 87,000 inhabitants, has been in the news lately as the site of brutal attacks on Poles by German nationalist and neo-Nazi groups.

Wex's group seems to have won the sympathy of the influential science advisory council Wissenschaftsrat. Reestablishing a university in Frankfurt is "an idea that could not be more welcome", says spokesman Wilhelm Krull. Support from Wissenschaftsrat would be crucial in gaining support from Bonn if the idea for a university in Frankfurt is backed by the government of Brandenburg, the Land (state) in which Frankfurt is located. (The city is $\mathbf{5 0 0}$ km east of its namesake in the west, Frankfurt on the Main.)

But Brandenburg may take its time in backing Wex's proposal. Although Brandenburg's governor, Manfred Stolpe, announced in his inaugural speech in counting engineers or medical doctors). They represent an almost insurmountable absorption problem for a country as small as Israel, which in mid-1989 had an estimated 4.37 million inhabitants.

Both the Israeli researchers and ministry officials interviewed are eager not to antagonize Germany, which over the years has spent DM400 million for cooperative projects with Israeli science. Scientific relations between the countries, which go back to 1959, even predate diplomatic relations, which began only in 1965 .

Germany, too, is eager to maintain a positive image in a country where people are inherently suspicious of its motives. "We have to keep persuading [the Israelis] of our goodwill," Gottstein says.

Nevertheless, Milner says the Germans have made the wrong move in this case, especially in the aftermath of the Persian Gulf war. "Germany has more work to do than before on its image," he says, because of the role played by German companies in delivering supplies to Iraq before and during the Gulf War. "The Germans need to practise more caution and restraint."

Steven Dickman
January that he plans to found three universities in Brandenburg, including one in Frankfurt, he may not have the money. Krull says that "three or even two universities" would be a big burden for Brandenburg (which currently has none), as the Land would ultimately have to finance them from its own tax revenues.

Stolpe has indicated that Brandenburg's capital city, Potsdam, is the preferred site for a university, which would be pieced together from the remnants of a pedagogics institute and an institute for law and administration.

Nevertheless, Wex is canvassing for Frankfurt as the site of at least a small university. A new university would not be burdened by the ideological ballast of the past, he points out.

Also - and here Krull concurs - it would be less expensive to start up a university that possessed faculties for only law, economics and social sciences, leaving the more expensive natural sciences for later.

Finally, Wex adds, western companies have expressed an interest in endowing chairs at such a university. But speed is of the essence, he warns. "They won't wait around forever."

Oddly enough, says Wex, he has so far received little support from those who would benefit the most from a university in Frankfurth: the city's residents. $\mathrm{He}$ attributes this to the general struggle for existence that has overtaken the citizens of eastern Germany.

Steven Dickman 